\title{
Point of care cutaneous imaging technology in melanoma screening and mole mapping
} H. William Higgins $\mathrm{II}^{1 *}$, Kachiu C. Lee ${ }^{2}$ and David J. Leffell ${ }^{1}$

Addresses: ${ }^{1}$ Department of Dermatology, Section of Cutaneous Oncology and Dermatologic Surgery, Yale University School of Medicine, 40 Temple Street 5A, New Haven, CT 06510, USA; ${ }^{2}$ Department of Dermatology, Brown University, 593 Eddy Street, APC 10, Providence, RI 02903, USA

*Corresponding author: H. William Higgins II (william.higgins@yale.edu)

Fl000Prime Reports 2014, 6:34 (doi:10.12703/P6-34)

All FI000Prime Reports articles are distributed under the terms of the Creative Commons Attribution-Non Commercial License (http://creativecommons.org/licenses/by-nc/3.0/legalcode), which permits non-commercial use, distribution, and reproduction in any medium, provided the original work is properly cited.

The electronic version of this article is the complete one and can be found at: http://f1000.com/prime/reports/m/6/34

\begin{abstract}
Melanoma is a malignancy of melanocytes or pigment-producing cells located predominantly in the skin. It is less common than other skin cancers but causes the greatest number of skin cancer-related deaths worldwide. The incidence of melanoma continues to increase and early detection is the most promising means of decreasing morbidity and mortality. Currently, physicians perform routine skin cancer screenings for melanoma without the benefit of imaging devices more advanced than handheld magnifiers or dermatoscopes. However, it is possible that the diagnosis of melanoma may be improved with technology that provides diagnostic discrimination beyond what is possible on routine inspection. This article reviews current and emerging technologies to aid in the diagnosis of melanoma. Ultimately, these advances may enhance the early diagnosis of melanoma.
\end{abstract}

\section{Introduction}

The incidence of malignant melanoma has been increasing by $2.6 \%$ annually over the last decade, with approximately 76,790 new cases resulting in 9,480 deaths in 2013 [1]. Additionally, melanoma is one of the most common forms of cancer in young adults and represents a significant health concern, particularly in terms of years of life lost $[1,2]$. A key prognostic indicator of melanoma is the depth of the lesion in millimeters at the time of diagnosis. Melanoma in situ, which is confined to the epidermis, is considered completely curable. Thin melanoma $(\leq 1 \mathrm{~mm})$ has a 5 year survival rate of $94 \%$ [2]. However, once melanoma has progressed and metastasized to other parts of the body, effective treatment is limited. The 5-year survival rate for patients with stage IV melanoma is less than $15 \%[1,2]$. Melanoma responds poorly to chemotherapy and radiation at this stage. Therefore, melanoma prognosis and cure rates can be dramatically improved by early diagnosis when the lesion is thinnest.

Clinical signs of early melanoma are often ambiguous; even the most experienced dermatologist may have difficulty identifying and differentiating it on a clinical basis from other pigmented lesions, such as atypical nevi. As a result of this clinical need, diagnostic tools have been developed to aid the clinician in deciding whether a lesion is suspicious enough to require biopsy.

Handheld epiluminescence microscopy or dermoscopy is a common modality used to inspect the pigment network pattern at the epidermodermal junction zone and to evaluate it for indicators of malignant transformation. More recently, the advent of computer-based systems provides sophisticated functionalities allowing for software algorithms to analyze specific features of lesions relevant to predicting malignancy. In addition, diagnostic aids for mole mapping, such as total body photography, improve the ability to longitudinally monitor patients who have too many moles to otherwise track for clinically significant changes. Both dermoscopy and mole mapping are becoming more commonplace [3]. Emerging technologies, such as in vivo reflectance confocal microscopy, optical coherence tomography, and even infrared imaging are currently being investigated to determine their utility 
for noninvasive diagnosis of melanoma. This article summarizes the currently available modalities used to aid in the detection of melanoma in conjunction with full body skin examinations.

\section{Total body photography}

One of the most frequently used tools, total body photography or mole mapping, is an effective means of monitoring pigmented lesions over time. This method uses high-quality, professional, full-body photographs to document the appearance and location of pigmented lesions on the body. High-resolution photographs of a single lesion under dermoscopy can also be taken, and is frequently used for monitoring suspicious lesions where biopsy is not yet indicated. At each physician visit, pigmented lesions from these photos are compared to those seen on a full body examination to aid in the identification of new and/or changing lesions. However, this method is time consuming and expensive, largely due to the cost of the photographer.

Analysis of individual, high-risk lesions over time based on comparisons with digital photos has been shown to be effective in detecting new and subtly changing pigmented lesions [4-6].

One observational trial of 530 high-risk patients with 53 diagnosed melanomas demonstrated increased sensitivity in detection of melanoma when digital dermoscopy photos were available for comparison, compared to lack of photographs. The chance of successfully detecting melanoma rose $17 \%$ with the use of digital dermoscopy [7]. Another trial found that total body photography assisted with detecting new or subtly changing melanomas, which did not fit classical clinical features of melanoma [6]. Melanomas detected were also thinner, although this could be a reflection of sampling bias since patients who undergo total body photography may also be more likely to follow-up with their dermatologists or employ other sun-protective measures [8]. Total body photography seems to be most useful in high-risk patents, including those with a strong history of melanoma or older individuals. In patients younger than 50, less than $1 \%$ of new lesions identified on full body skin examination, using their total body photographs as a reference point, were diagnosed as melanoma. In comparison, in the cohort of patients 50 years and older, $30 \%$ of new lesions discovered using the same method were diagnosed as melanoma [9]. Several other studies have demonstrated the usefulness of total body photography in the detection of melanoma in high-risk populations $[4,5,9,10]$.

Despite these documented benefits in detecting melanoma using total body photography, there is still a lack of data to support whether this modality leads to decreased morbidity and/or mortality [11-13]. Total body photography, while effective for tracking clinical change in lesions or the development of new lesions, is time-consuming and laborious. In addition, in the US, health insurance often does not cover the cost of taking the professional photos, which ranges from $\$ 400-\$ 500[14,15]$.

Traditional digital total body photography relies on physical photographs, which the patient brings to each appointment, or which the physician stores as part of the paper medical record. In contrast, several computerized imaging systems store sequential digital images. MoleMax (Derma Medical Systems, Vienna, Austria), FotoFinder (FotoFinder Systems Inc, Columbia, MD, USA), MoleMap CD (DigitalDerm Inc, Columbia, SC, USA), Smartscope (MidCon Distribution Inc, Overland Park, KS, USA), DermSpectra (DermSpectra, Tuscon, AZ, USA), DermaTrak Skin Imaging Centers (Canfield Scientific, Fairfield, NJ, USA), and Melanoscan (Melanoscan Inc, Stamford, CT, USA) all offer alternatives to traditional full body photography. All of these devices allow for comparison of high-resolution digital images, and some have software that calculates the likelihood of malignancy based on clinical features. While these devices are promising, many lack large-scale clinical trials supporting their efficacy. Of published studies in peer-reviewed journals that examined these devices, the majority are sponsored by the device company. All of these devices need to be coupled with clinical judgment when examining any patient for melanoma.

\section{Confocal scanning laser microscopy}

Confocal scanning laser microscopy (CSLM) uses the inherent reflective properties of the tissue to distinguish between various skin structures and ultrastructures [16]. This non-invasive technology has a hand-piece that is applied to the skin, with the resulting image showing up on a monitor. CSLM devices operate in two forms: reflectance and fluorescence mode. Reflectance mode is used in clinical practice, while fluorescence mode is still mainly confined to research [16]. Under reflective CSLM, melanin granules and melanosomes have a higher refractive index than surrounding structures, which can be distinguished on the confocal microscope. CSLM can even detect amelanotic melanomas due to the presence of melanosomes in amelanotic lesions [17]. Additionally, one study examining 27 melanomas compared to 90 benign nevi found that CSLM had a sensitivity and specificity of $88 \%$ and $98 \%$, respectively [18]. Another study comparing 20 melanomas and 50 benign nevi using CSLM found a sensitivity and specificity of $98 \%$ and 99\%, respectively [19]. Positive predictive values have been reported to be as high as $97.5 \%$ in 
diagnosing melanoma using CSLM [19-21]. Compared to handheld dermoscopy (in a study of 37 melanomas and 88 benign nevi) the sensitivity and specificity of CSLM was $97 \%$ and $83 \%$, respectively. Sensitivity and specificity of dermoscopy was $89 \%$ and $84 \%$, respectively [21].

Advances in CSLM technology promise to make this a valuable tool in improving diagnostic accuracy and ease of use. This technology provides visualization to the level of the superficial dermis and has a resolution comparable to that of standard pathology or $5 \mu \mathrm{m}$ permanent sections. In addition, it allows for non-invasive imaging of multiple lesions during the same session. A decade ago, CSLM devices were large and bulky. Technologic advances have contributed to the development of more portable CSLM devices with handheld imaging pieces connected to a monitor.

Despite the apparent potential of CSLM, its use is limited by several factors. CSLM requires a high level of experience to interpret the images. Upfront costs are also considerable, with commercially available CSLM equipment costing upwards of $\$ 50,000$. After purchasing the equipment, additional supplies are necessary to evaluate each lesion. This can represent an additional evaluation cost of $\$ 1.00$ per lesion.

\section{Multispectral imaging}

Multispectral technology uses radiation ranging from $400-1000 \mathrm{~nm}$ to provide the end-user with a series of digital images [14]. They provide multispectral information in the spatial and spectral domains by capturing radiation intensity at a specific point and as a function of wavelength, respectively. These newer devices hold promise in distinguishing between malignant and benign pigmented lesions.

MelaFind (MELA Sciences Inc, Irvington, NY, USA) uses multispectral technology to quantitatively characterize suspicious lesions. This device evaluates the lesion in 10 different spectral bands, which range from 430-950 nm. The images are evaluated by proprietary software, which determines the border of the lesion and analyzes its parameters, such as color variation, asymmetry, perimeter and textural changes. Clinicians must first use their own clinical judgment in determining which lesions should be evaluated by MelaFind, as the technology is highly inaccurate if used on lesions known to be benign such as seborrheic keratosis or cherry angiomas [14,22-24]. This device is designed to aid the physician in determining which lesions to biopsy, providing binary outcomes of positive (biopsy should be considered) or negative (lesion is less suspicious). Because of its binary output, user experience is not as essential as it is with other devices, such as CSLM, but does assume clinical expertise in diagnosing common dermatologic lesions. In a multicenter study on MelaFind of 1383 patients, the sensitivity of MelaFind was $98 \%$. The device detected mostly thin melanomas or borderline lesions (high-grade dysplastic nevi, atypical melanocytic proliferations/hyperplasias). In lesions histologically proven to be melanoma, MelaFind's average specificity was $9.9 \%$, which was higher than the $3.7 \%$ specificity of dermatologists. Of note, this multicentered study was sponsored by MELA Sciences, which produces the MelaFind device [25]. Currently, the cost of imaging ranges from $\$ 25$ to $\$ 175$ for evaluation of one lesion and around $\$ 25$ for additional lesions $[15,26]$.

The SIAscope (Spectrophotometric Intracutaneous Analysis, made by Biocompatibles, Farnham, Surrey, UK) uses multispectral imaging to detect three chromophores: melanin (in the epidermis and upper dermis), hemoglobin, and collagen. Using a handheld device connected to a monitor, the physician is able to evaluate the pattern of each chromophore in clinically suspicious lesions. In a study of 348 pigmented lesions (52 melanomas), sensitivity and specificity for melanoma was $80 \%$ and $83 \%$, respectively [27]. In a cohort of primary care providers, SIAscope's sensitivity was $94 \%$, with a false negative rate of $4 \%$ [28]. Another study, examining 881 pigmented lesions (31 melanomas), found no difference in the sensitivity and specificity of SIAscope use compared to dermsocopy use by dermatologists [29]. Thus, it is unclear whether this device provides any more benefits than conventionally used tools (such as dermoscopy) when performing a full body skin examination. The MoleMate system incorporates the SIAscope device with a diagnostic algorithm for primary care physicians to use. Its efficacy is currently under investigation [30-32]. For optimal use, the SIAscope requires experienced users who can accurately interpret SIAscope images. Additionally, the SIAscope algorithms use features common to benign lesions, thus classifying benign lesions such as seborrheic keratosis or cherry angiomas as suspicious [33].

\section{Other technologies on the horizon}

Several other types of technologies are in development for the detection of melanoma. Infrared spectroscopy [34], Raman spectroscopy $[35,36]$, thermographic imaging [37], tissue elastography [38], fiber diffraction [39], electric impedence spectroscopy $[40,41]$, and noninvasive genomic detection [42] may all play a role in assisting with the diagnosis of melanoma in the future. Mobile smartphone apps also offer an opportunity for patients to monitor their own skin for suspicious lesions, but current apps have, thus far, been shown to be insufficiently accurate $[43,44]$. 


\section{Use of imaging modalities by primary care physicians for melanoma screening and mole monitoring}

Cutaneous imaging modalities can be used to enhance screening for melanoma by primary care physicians as well as the monitoring of high-risk patients by dermatologists. Dermoscopy can be an effective tool for trained primary care physicians to screen for melanoma. In several studies involving primary care physicians, dermoscopy increased their sensitivity in detecting malignant lesions, leading to improvements in confidence and accuracy in referring suspicious lesions to dermatologists $[11,45,46]$. However, learning dermoscopy can be a time-consuming process for primary care physicians, with the average general practitioner requiring 30 hours of internet-based learning to acquire adequate skills in interpreting dermoscopy images [47]. For dermatologists, dermoscopy can also serve as a valuable tool in monitoring high-risk patients, leading to improved diagnostic accuracy when compared to naked eye examination $[48,49]$.
Total body photography is an effective tool for detecting new or changing lesions by patients, primary care physicians, and dermatologists. In particular, total body photography can improve self-skin examination accuracy and melanoma detection by patients $[50,51]$. Mole mapping can also improve patients' self-confidence and knowledge when conducting skin self-examinations [50]. Thus, it can be used for both screening purposes and monitoring of high-risk lesions.

CSLM requires significant operator experience to interpret images, and the equipment is prohibitively expensive for use in primary care. Due to these factors, CSLM is typically used only at major academic centers with specialized pigmented lesion programs. CSLM can significantly improve specificity in detection of melanoma compared to dermoscopy alone [52].

MelaFind's efficacy in detecting malignancy has only been evaluated in dermatologists, showing increased sensitivity and specificity when diagnosing melanomas [15,25].

Table I. Imaging technologies

\begin{tabular}{|c|c|c|c|c|c|c|c|}
\hline Modality & Benefits & Limitations & Cost & $\begin{array}{l}\text { Use by primary } \\
\text { care }\end{array}$ & $\begin{array}{l}\text { Use by } \\
\text { dermatologists }\end{array}$ & Sensitivity & Specificity \\
\hline $\begin{array}{l}\text { Total body } \\
\text { photography }\end{array}$ & $\begin{array}{l}\text { Allows provider and } \\
\text { patient to monitor } \\
\text { pigmented lesions } \\
\text { over time. }\end{array}$ & $\begin{array}{l}\text { Time consuming and } \\
\text { expensive } \\
\text { largely due to the } \\
\text { cost of the } \\
\text { photographer. }\end{array}$ & $\begin{array}{l}\$ 400-500 \text { (varies } \\
\text { by photographer). }\end{array}$ & $\begin{array}{l}\text { May improve skin } \\
\text { examination quality } \\
\text { by primary care } \\
\text { physicians, although } \\
\text { no randomized } \\
\text { controlled trials } \\
\text { have been } \\
\text { conducted. }\end{array}$ & $\begin{array}{l}\text { May improve skin } \\
\text { examination quality } \\
\text { by dermatologists, } \\
\text { although no } \\
\text { randomized } \\
\text { controlled trials } \\
\text { have been } \\
\text { conducted. }\end{array}$ & Unknown & Unknown \\
\hline $\begin{array}{l}\text { Confocal } \\
\text { scanning } \\
\text { laser } \\
\text { microscopy } \\
\text { (CSLM) }\end{array}$ & $\begin{array}{l}\text { Handheld device } \\
\text { that provides high- } \\
\text { resolution visualization } \\
\text { (comparable to } \\
\text { standard pathology) } \\
\text { to the level of the } \\
\text { superficial dermis. }\end{array}$ & $\begin{array}{l}\text { Requires a high } \\
\text { level of operator } \\
\text { experience, } \\
\text { relatively high } \\
\text { upfront cost to the } \\
\text { provider. }\end{array}$ & $\begin{array}{l}\$ 50,000 \text { per } \\
\text { device. } \$ 1 \\
\text { (supplies) to } \\
\text { image a lesion. }\end{array}$ & $\begin{array}{l}\text { No, prohibitively } \\
\text { expensive and high } \\
\text { level of experience } \\
\text { required for device } \\
\text { use and image } \\
\text { interpretation. }\end{array}$ & $\begin{array}{l}\text { Yes, but usually } \\
\text { academic centers } \\
\text { with specialized } \\
\text { pigmented lesion } \\
\text { programs. }\end{array}$ & $88-98 \%$ & $83-99 \%$ \\
\hline MelaFind & $\begin{array}{l}\text { Simple binary output } \\
\text { (biopsy vs. don't } \\
\text { biopsy). User } \\
\text { experience is not as } \\
\text { essential as with } \\
\text { other devices such } \\
\text { as CSLM. }\end{array}$ & $\begin{array}{l}\text { Requires clinical } \\
\text { expertise in } \\
\text { diagnosing } \\
\text { common } \\
\text { dermatologic } \\
\text { lesions, e.g. } \\
\text { differentiating nevi } \\
\text { from seborrheic } \\
\text { keratoses }\end{array}$ & $\begin{array}{l}\$ 7000 \text { per device. } \\
\$ 25 \text { to } \$ 175 \text { for } \\
\text { evaluation of one } \\
\text { lesion and around } \\
\$ 25 \text { for additional } \\
\text { lesions (not } \\
\text { covered by } \\
\text { insurance). }\end{array}$ & $\begin{array}{l}\text { No, although } \\
\text { analysis algorithm } \\
\text { and binary output } \\
\text { holds potential for } \\
\text { use by a primary } \\
\text { care physician. } \\
\text { Current device } \\
\text { algorithm requires } \\
\text { training to identify a } \\
\text { clinically suspicious } \\
\text { lesion suitable for } \\
\text { imaging. }\end{array}$ & $\begin{array}{l}\text { Yes, improves the } \\
\text { sensitivity and } \\
\text { specificity of } \\
\text { dermatologists in } \\
\text { detecting melanoma. }\end{array}$ & $98 \%$ & $10 \%$ \\
\hline Siascope & $\begin{array}{l}\text { Handheld device, } \\
\text { provides high-quality } \\
\text { images, less expensive } \\
\text { than other devices. }\end{array}$ & $\begin{array}{l}\text { Operator } \\
\text { dependent, requires } \\
\text { experienced users } \\
\text { who can accurately } \\
\text { interpret SIAscope } \\
\text { images. }\end{array}$ & $\begin{array}{l}\$ 5000 \text { - } \$ 8000 \text { per } \\
\text { device. }\end{array}$ & $\begin{array}{l}\text { No, although a } \\
\text { scoring algorithm } \\
\text { targeted at primary } \\
\text { care physicians is } \\
\text { currently in } \\
\text { development and } \\
\text { shows promise. }\end{array}$ & $\begin{array}{l}\text { Yes, but operator } \\
\text { dependent. }\end{array}$ & $80-94 \%$ & $83 \%$ \\
\hline
\end{tabular}


Because MelaFind depends on the clinician's judgment to first identify a suspicious lesion to evaluate, it can result in inter-user variability. However, MelaFind's analysis algorithm of suspicious lesions and binary output does hold potential for use by a primary care physician trained to first identify a clinically worrisome lesion [53]. Further studies involving primary care physicians need to be conducted to evaluate its efficacy in this population.

SIAscope holds promise for use by primary care physicians. When used by primary care physicians, SIAscope has a sensitivity of $94 \%$, with a false negative rate of $4 \%$ [28]. In the UK and Australia, a scoring algorithm was recently developed, tailored to primary care physicians using SIAscope [32,33]. Additional studies evaluating the efficacy of these protocols are underway.

\section{Conclusion}

While recent technological advances in the cutaneous imaging and diagnosis of melanoma are promising, there are still significant barriers to their widespread implementation (for a summary of imaging technologies see table 1). These modalities require time, appropriate training, and experience for proper use. To encourage widespread use, these technologies need to provide accurate information to the clinician in a time-efficient manner. Additionally, they need to show improved patient outcomes through decreased morbidity and/or mortality. Adoption by primary care physicians will likely enhance the rate of early diagnosis of melanoma and decrease morbidity and mortality in populations at risk.

\section{Abbreviations}

CSLM, confocal scanning laser microscopy.

\section{Disclosures}

The authors declare that they have no disclosures.

\section{References}

I. Siegel R, Naishadham D, Jemal A: Cancer statistics, 20 I3. CA Cancer J Clin 2013, 63:11-30.

\section{FlOOOPrime} RECOMMENDED

2. American Cancer Society: Cancer Facts \& Figures 2013. 2013.

3. Chiu V, Won E, Malik M, Weinstock MA: The use of molemapping diagrams to increase skin self-examination accuracy. J Am Acad Dermatol 2006, 55:245-50.

4. Salerni G, Carrera C, Lovatto L, Martí-Laborda RM, Isern G, Palou J, Alós L, Puig S, Malvehy J: Characterization of II52 lesions excised over 10 years using total-body photography and digital dermatoscopy in the surveillance of patients at high risk for melanoma. J Am Acad Dermatol 2012, 67:836-45.

\section{FlOOOPrime}

5. Salerni G, Carrera C, Lovatto L, Puig-Butille JA, Badenas C, Plana E, Puig S, Malvehy J: Benefits of total body photography and digital dermatoscopy ("two-step method of digital follow-up") in the early diagnosis of melanoma in patients at high risk for melanoma. J Am Acad Dermatol 2012, 67:el7-27.

\section{FlOOOPrime
RECOMMENDED}

6. Feit NE, Dusza SW, Marghoob AA: Melanomas detected with the aid of total cutaneous photography. Br J Dermatol 2004, I 50:706-| 4.

\section{FlOOOPrime \\ RECOMMENDED}

7. Haenssle HA, Krueger U, Vente C, Thoms K, Bertsch HP, Zutt M, Rosenberger A, Neumann C, Emmert S: Results from an observational trial: digital epiluminescence microscopy followup of atypical nevi increases the sensitivity and the chance of success of conventional dermoscopy in detecting melanoma. J Invest Dermatol 2006, I 26:980-5.

\section{FlOOOPrime}

\section{RECOMMENDED}

8. Wang SQ, Kopf AW, Koenig K, Polsky D, Nudel K, Bart RS: Detection of melanomas in patients followed up with total cutaneous examinations, total cutaneous photography, and dermoscopy. J Am Acad Dermatol 2004, 50: I5-20.

9. Banky JP, Kelly JW, English DR, Yeatman JM, Dowling JP: Incidence of new and changed nevi and melanomas detected using baseline images and dermoscopy in patients at high risk for melanoma. Arch Dermatol 2005, I41:998-1006.

\section{FIOOOPrime}

10. Bauer J, Blum A, Strohhäcker U, Garbe C: Surveillance of patients at high risk for cutaneous malignant melanoma using digital dermoscopy. Br J Dermatol 2005, I 52:87-92.

II. Menzies SW, Emery J, Staples M, Davies S, McAvoy B, Fletcher J, Shahid KR, Reid G, Avramidis M, Ward AM, Burton RC, Elwood JM: Impact of dermoscopy and short-term sequential digital dermoscopy imaging for the management of pigmented lesions in primary care: a sequential intervention trial. $\mathrm{Br} J$ Dermatol 2009, I6 I: I270-7.

FlOOOPrime RECOMMENDED

12. Marghoob AA, Halpern AC: Biopsy rates in patients with and without total body photography. J Am Acad Dermatol 2008, 58:894-5.

13. Risser J, Pressley Z, Veledar E, Washington C, Chen SC: The impact of total body photography on biopsy rate in patients from a pigmented lesion clinic. J Am Acad Dermatol 2007, 57:428-34.

14. Ferris LK, Harris RJ: New diagnostic aids for melanoma. Dermatol Clin 2012, 30:535-45.

15. Kupetsky EA, Ferris LK: The diagnostic evaluation of MelaFind multi-spectral objective computer vision system. Expert Opin Med Diagn 2013, 7:405-II.

16. Meyer LE, Otberg N, Sterry W, Lademann J: In vivo confocal scanning laser microscopy: comparison of the reflectance and fluorescence mode by imaging human skin. J Biomed Opt 2006, I I:440I2.

\section{FlOOPrime}

\section{RECOMMENDED}

17. Busam KJ, Hester K, Charles C, Sachs DL, Antonescu CR, Gonzalez S, Halpern AC: Detection of clinically amelanotic malignant melanoma and assessment of its margins by in vivo confocal scanning laser microscopy. Arch Dermatol 200I, I37:923-9. 
18. Gerger A, Koller S, Kern T, Massone C, Steiger K, Richtig E, Kerl H, Smolle J: Diagnostic applicability of in vivo confocal laser scanning microscopy in melanocytic skin tumors. J Invest Dermatol 2005, I 24:493-8.

\section{FlOOOPrime
RECOMMENDED}

19. Gerger A, Hofmann-Wellenhof R, Langsenlehner U, Richtig E, Koller S, Weger W, Ahlgrimm-Siess V, Horn M, Samonigg H, Smolle J: In vivo confocal laser scanning microscopy of melanocytic skin tumours: diagnostic applicability using unselected tumour images. Br J Dermatol 2008, 158:329-33.

\section{FIOOOPRime
RECOMMENDED}

20. Gerger A, Koller S, Weger W, Richtig E, Kerl H, Samonigg H, Krippl P, Smolle J: Sensitivity and specificity of confocal laser-scanning microscopy for in vivo diagnosis of malignant skin tumors. Cancer 2006, 107:193-200.

21. Langley RGB, Walsh N, Sutherland AE, Propperova I, Delaney L, Morris SF, Gallant C: The diagnostic accuracy of in vivo confocal scanning laser microscopy compared to dermoscopy of benign and malignant melanocytic lesions: a prospective study. Dermatology (Basel) 2007, 2I 5:365-72.

\section{FloOOPrime \\ RECOMMENDED}

22. Computer-aided multispectral digital analysis (MelaFind) for assessing atypical skin lesions. Manag Care 2012, 21:12-3.

23. Gutkowicz-Krusin D, Elbaum M, Jacobs A, Keem S, Kopf AW, Kamino H, Wang S, Rubin P, Rabinovitz H, Oliviero M: Precision of automatic measurements of pigmented skin lesion parameters with a MelaFind(TM) multispectral digital dermoscope. Melanoma Res 2000, 10:563-70.

24. Elbaum M, Kopf AW, Rabinovitz HS, Langley RG, Kamino H, Mihm MC, Sober AJ, Peck GL, Bogdan A, Gutkowicz-Krusin D, Greenebaum M, Keem S, Oliviero M, Wang S: Automatic differentiation of melanoma from melanocytic nevi with multispectral digital dermoscopy: a feasibility study. J Am Acad Dermatol 200I, 44:207-I8.

25. Monheit G, Cognetta AB, Ferris L, Rabinovitz H, Gross K, Martini M, Grichnik JM, Mihm M, Prieto VG, Googe P, King R, Toledano A, Kabelev N, Wojton M, Gutkowicz-Krusin D: The performance of MelaFind: a prospective multicenter study. Arch Dermatol 20II, 147:188-94.

\section{FlOOOPrime} RECOMMENDED

26. Singer N: Dissent Over a Device to Help Find Melanoma. New York Times; 30 July 2013. [http://nytimes.com/2013/07/2I/business/ dissent-over-a-device-to-help-find-melanoma.html?_r=0]

27. Moncrieff M, Cotton S, Claridge E, Hall P: Spectrophotometric intracutaneous analysis: a new technique for imaging pigmented skin lesions. $\mathrm{Br} J$ Dermatol 2002, 146:448-57.

\section{FlOOOPrime}

RECOMMENDE

28. Govindan K, Smith J, Knowles L, Harvey A, Townsend P, Kenealy J: Assessment of nurse-led screening of pigmented lesions using SIAscope. J Plast Reconstr Aesthet Surg 2007, 60:639-45.

\section{FlOOOPrime} RECOMMENDED

29. Haniffa MA, Lloyd JJ, Lawrence CM: The use of a spectrophotometric intracutaneous analysis device in the real-time diagnosis of melanoma in the setting of a melanoma screening clinic. Br J Dermatol 2007, I 56:1350-2.

\section{FlOOOPRime
RECOMMENDED}

30. Wilson ECF, Emery JD, Kinmonth AL, Prevost AT, Morris HC, Humphrys E, Hall PN, Burrows N, Bradshaw L, Walls J, Norris P,
Johnson M, Walter FM: The cost-effectiveness of a novel SIAscopic diagnostic aid for the management of pigmented skin lesions in primary care: a decision-analytic model. Value Health 2013, 16:356-66.

31. Walter FM, Morris HC, Humphrys E, Hall PN, Kinmonth AL, Prevost AT, Wilson EC, Burrows N, Norris P, Johnson M, Emery J: Protocol for the MoleMate UK Trial: a randomised controlled trial of the MoleMate system in the management of pigmented skin lesions in primary care [ISRCTN 79932379]. BMC Fam Pract 2010, I1:36.

32. Wood A, Morris H, Emery J, Hall PN, Cotton S, Prevost AT, Walter FM: Evaluation of the MoleMate training program for assessment of suspicious pigmented lesions in primary care. Inform Prim Care 2008, 16:41-50.

33. Emery JD, Hunter J, Hall PN, Watson AJ, Moncrieff M, Walter FM: Accuracy of SIAscopy for pigmented skin lesions encountered in primary care: development and validation of a new diagnostic algorithm. BMC Dermatol 2010, 10:9.

34. Hammody Z, Argov S, Sahu RK, Cagnano E, Moreh R, Mordechai S: Distinction of malignant melanoma and epidermis using IR micro-spectroscopy and statistical methods. Analyst 2008, 133:372-8.

35. Lui H, Zhao J, McLean D, Zeng H: Real-time Raman spectroscopy for in vivo skin cancer diagnosis. Cancer Res 2012, 72:249|-500.

36. Philipsen PA, Knudsen L, Gniadecka M, Ravnbak MH, Wulf HC: Diagnosis of malignant melanoma and basal cell carcinoma by in vivo NIR-FT Raman spectroscopy is independent of skin pigmentation. Photochem Photobiol Sci 2013, I 2:770-6.

37. Herman C, Cetingul MP: Quantitative visualization and detection of skin cancer using dynamic thermal imaging. $J$ Vis Exp 20II, e2679.

38. Hinz T, Wenzel J, Schmid-Wendtner M: Real-time tissue elastography: a helpful tool in the diagnosis of cutaneous melanoma? J Am Acad Dermatol 20I I, 65:424-6.

39. James V]: Fiber diffraction of skin and nails provides an accurate diagnosis of malignancies. Int J Cancer 2009, I 25: 133-8.

40. Aberg P, Birgersson U, Elsner P, Mohr P, Ollmar S: Electrical impedance spectroscopy and the diagnostic accuracy for malignant melanoma. Exp Dermatol 20II, 20:648-52.

4I. Har-Shai Y, Glickman YA, Siller G, McLeod R, Topaz M, Howe C, Ginzburg A, Zamir B, Filo O, Kenan G, Ullmann Y: Electrical impedance scanning for melanoma diagnosis: a validation study. Plast Reconstr Surg 2005, I I 6:782-90.

42. Wachsman W, Morhenn V, Palmer T, Walls L, Hata T, Zalla J, Scheinberg R, Sofen H, Mraz S, Gross K, Rabinovitz H, Polsky D, Chang S: Noninvasive genomic detection of melanoma. $\mathrm{Br}$ J Dermatol 2011, 164:797-806

43. Wolf JA, Moreau JF, Akilov O, Patton T, English JC, Ho J, Ferris LK: Diagnostic inaccuracy of smartphone applications for melanoma detection. JAMA Dermatol 2013, 149:422-6.

\section{FlOOOPrime}

44. Burki TK: Diagnostic accuracy of smartphone applications. Lancet Oncol 2013, 14:e90.

45. Marghoob AA, Usatine RP, Jaimes N: Dermoscopy for the family physician. Am Fam Physician 2013, 88:44I-50.

\section{FlOOOPrime
RECOMMENDED}

46. Herschorn A: Dermoscopy for melanoma detection in family practice. Can Fam Physician 2012, 58:740-5, e372-8.

\section{FlOOOPrime
RECOMMENDED}

47. Bowns IR, Collins K, Walters SJ, McDonagh AJG: Telemedicine in dermatology: a randomised controlled trial. Health Technol Assess 2006, I 0:iii-iv, ix-xi, I-39.

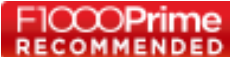


48. Vestergaard ME, Macaskill P, Holt PE, Menzies SW: Dermoscopy compared with naked eye examination for the diagnosis of primary melanoma: a meta-analysis of studies performed in a clinical setting. $\mathrm{Br} J$ Dermatol 2008, I59:669-76.

\section{FlOOOPrime \\ RECOMMENDED}

49. Kittler $\mathrm{H}$, Pehamberger $\mathrm{H}$, Wolff $\mathrm{K}$, Binder M: Diagnostic accuracy of dermoscopy. Lancet Oncol 2002, 3:159-65.

50. McWhirter JE, Hoffman-Goetz L: Visual images for patient skin self-examination and melanoma detection: a systematic review of published studies. J Am Acad Dermatol 2013, 69:47-55.
5I. Hamidi R, Peng D, Cockburn M: Efficacy of skin self-examination for the early detection of melanoma. Int J Dermatol 2010, 49:126-34.

\section{FloOPrime}

RECOMMENDED

52. Alarcon I, Carrera C, Palou J, Alos L, Malvehy J, Puig S: Impact of in vivo reflectance confocal microscopy on the number needed to treat melanoma in doubtful lesions. Br J Dermatol 2013, [Epub ahead of print].

53. Tomatis S, Bono A, Bartoli C, Carrara M, Lualdi M, Tragni G, Marchesini R: Automated melanoma detection: multispectral imaging and neural network approach for classification. Med Phys 2003, 30:212-21. 